\title{
Implementasi Hak Servituut pada Pelaksanaan Pendaftaran Tanah Sistematis Lengkap di Kabupaten Bekasi
}

\author{
Nugraha Salman Ishaya ${ }^{1}$, Haryo Budhiawan ${ }^{2}$, Koes Widarbo ${ }^{3}$ \\ ${ }^{1}$ Kantor Pertanahan Kota Cimahi, Jl. Encep Kartawiria No. 21A, Kota Cimahi, Jawa Barat \\ ${ }^{2}$ Sekolah Tinggi Pertanahan Nasional, Jl. Tata Bumi No. 5 Banyuraden, Yogyakarta \\ ${ }^{3}$ Sekolah Tinggi Pertanahan Nasional, Jl. Tata Bumi No. 5 Banyuraden, Yogyakarta \\ * Korespondensi: email: nuge3131@gmail.com
}

\begin{tabular}{|c|c|}
\hline ARTICLE INFO & ABSTRACT \\
\hline $\begin{array}{l}\text { Keywords : } \\
\text { PTSL, servituut rights, social } \\
\text { functions on land, transfer of } \\
\text { land rights } \\
\text { Received: } 15 \text { August, } 2021 \\
\text { Reviewed: } 26 \text { August, } 2021 \\
\text { Accepted: October 24, } 2021\end{array}$ & $\begin{array}{l}\text { The Ministry of ATR/BPN organizes PTSL in order to accelerate fair and equitable } \\
\text { land registration and anticipate disputes over land use and spatial planning. In } \\
\text { anticipation of road access disputes, the Land Office of Bekasi Regency } \\
\text { implements a servituut rights policy in PTSL activities. This research was conducted } \\
\text { to gain an understanding of how servituut rights are being implemented as an } \\
\text { actualization of the principle of social function on land in the PTSL program } \\
\text { administered by the Land Office of Bekasi Regency. This research uses empirical } \\
\text { legal research methods. The findings showed that the policy's implementation is } \\
\text { motivated by the dualism status of roads, the existence of regional development } \\
\text { and land acquisition, and the relatively high land value. The policy's } \\
\text { implementation has taken on a new meaning, shifting from restrictions on land } \\
\text { use to the obligation to surrender some land rights. For PTSL participants who } \\
\text { agree to surrender a portion of their road rights, the transfer of rights is } \\
\text { administered through a Declaration Letter on Land Boundaries and Land Areas. If } \\
\text { there is disagreement, the plot of land is classified as K3, and a land register is } \\
\text { formed. }\end{array}$ \\
\hline
\end{tabular}

\section{INFO ARTIKEL}

\section{Kata Kunci:}

PTSL, hak servituut, fungsi sosial atas tanah, penyerahan hak atas tanah

\section{How To Cite :}

Ishaya, N. S., Budhiawan, H., Koes Widarbo, K. (2021). Implementasi Hak Servituut Pada Pelaksanaan Pendaftaran Sistematis Lengkap Di Kabupaten Bekasi. Marcapada: Jurnal Kebijakan Pertanahan, 1(1), 1-16

\section{ABSTRAK}

Kementerian ATR/BPN menyelenggarakan PTSL untuk percepatan pendaftaran tanah yang adil, merata dan mengantisipasi sengketa pemanfaatan dan penataan ruang. Kantor Pertanahan Kabupaten Bekasi menerapkan kebijakan hak servituut dalam kegiatan PTSL sebagai antisipasi terjadinya sengketa terkait akses jalan. Penelitian ini dilaksanakan untuk memahami implementasi hak servituut sebagai aktualisasi dari asas fungsi sosial atas tanah pada program PTSL di Kantor Pertanahan Kabupaten Bekasi. Penelitian ini menggunakan metode penelitian hukum empiris. Hasil penelitian menunjukkan penerapan kebijakan hak servituut dilatarbelakangi dualisme status jalan, adanya pengembangan wilayah dan pembebasan tanah, serta nilai tanah yang relatif tinggi. Implementasi kebijakan tersebut telah mengalami perubahan makna, dari pembatasan penggunaan tanah menjadi kewajiban penyerahan sebagian hak atas tanah. Terhadap peserta PTSL yang setuju menyerahkan sebagian haknya untuk jalan, administrasi penyerahan hak dilaksanakan dalam Surat Pernyataan Atas Batas Tanah dan Luas Tanah. Untuk pihak yang tidak setuju, bidang tanahnya dimasukkan dalam kategori K3 dan dibuatkan daftar tanah. 


\section{A. Pendahuluan}

Tanah memiliki peran yang sangat vital dalam setiap ranah kehidupan manusia. Pada perspektif sosial, ekonomi dan budaya, tanah tidak hanya menjadi wadah untuk melangsungkan berbagai bentuk aktivitas atau sebagai penyedia sumber daya dalam pemenuhan kebutuhan dasar hidup saja, namun lebih dari itu tanah juga berfungsi sebagai pendukung faktor ekonomis dalam menciptakan segala hal yang berhasil guna. Limbong (2012) menyebutkan bahwa segenap bangsa Indonesia memiliki ikatan batin yang abadi terhadap tanah yang bersifat magis religius.

Guna mewujudkan kepastian hukum perihal hak-hak atas tanah bagi seluruh rakyat Indonesia, sesuai mandat Pasal 19 Undang-Undang Nomor 5 Tahun 1960 (UUPA) Pemerintah melaksanakan kegiatan pendaftaran tanah yang ruang lingkupnya seluruh wilayah kedaulatan Republik Indonesia. Percepatan kegiatan pendaftaran tanah perlu dilakukan demi terwujudnya penyegeraan tertib administrasi pertanahan. Kementerian Agraria dan Tata Ruang/Badan Pertanahan Nasional (Kementerian ATR/BPN) menyelenggarakan inovasi berbasis program strategis nasional, yaitu Pendaftaran Tanah Sistematis Lengkap (PTSL). Pemerintah memastikan terlaksananya percepatan pelaksanaan pendaftaran tanah secara adil dan merata yang memberikan kepastian hukum dan perlindungan hukum. Harapan ke depannya selain dapat meningkatkan kesejahteraan dan kemakmuran rakyat Indonesia, juga dapat mencegah timbulnya sengketa dan konflik pertanahan (Widjayanto dalam Sukoyo, 2019).

Salah satu dampak dari meningkatnya pembangunan pada sektor permukiman membawa konsekuensi makin banyaknya tanah yang dibutuhkan untuk pembuatan jaringan jalan menuju jalan umum. Upaya untuk memenuhi kebutuhan akan jalan, biasanya pemilik tanah yang memiliki akses langsung dengan jalan umum akan memberikan akses jalan kepada pemilik tanah yang berada di belakang atau yang terhalang sekedar untuk dapat melintas keluar-masuk ke jalan umum. Hukum Adat mengistilahkannya sebagai hak melintasi tanah orang lain (Gueci, 2016). Selain dalam Hukum Adat, mengenai pemberian jalan sebelumnya pernah diatur dalam Kitab Undang-Undang Hukum Perdata (KUHPerdata) yang disebut sebagai Hak Servituut.

Penelitian mengenai hak servituut ini mengacu pada penelitian-penelitian sebelumnya. Penelitian Dakhriawan (2014) berkesimpulan bahwa regulasi hak pengabdian pekarangan hanya terbatas pada pertimbangan dan kebijakan Kantor Pertanahan yang terpengaruh status hak atas tanah. Tanah Bekas Milik Adat atau Tanah Negara mendapatkan perlakuan yang berbeda dalam proses pendaftaran tanah pertama kali. Fitria (2014) mengemukakan bahwa Hak Servituut masih berlaku berdasarkan ketentuan Konversi Pasal I Ayat (6) UUPA dinyatakan bahwa Hak Servituut masih menjadi suatu hak dan membuktikan bahwa Hak Servituut masih berlaku di Indonesia karena Yurisprudensi mengenai Hak Servituut dikeluarkan setelah berlakunya UUPA. Wirandhana (2017) dalam penelitiannya berkesimpulan bahwa setiap jenis hak atas tanah terikat kewajiban fungsi sosial atau seperti hak Servituut dalam BW dan Hak Milik yang pada awalnya merupakan hak yang tidak dapat diganggu gugat (droit inviolable in sacre), namun sifat tersebut tidak berlaku sepenuhnya lagi karena berkenaan dengan pembatasan, misalnya dibatasi oleh hukum tetangga, hukum tata usaha dan larangan menyalahgunakan hak (misbruik van recht). Kemudian Sholihah (2018) mengemukakan bahwa belum ada hukum positif yang mengatur mengenai penyelesaian sengketa akses jalan yang diperoleh dari hak pengabdian pekarangan dan penyelesaian sengketa 
melalui jalur mediasi dipandang lebih menyelesaikan masalah dibandingkan melalui jalur litigasi, baik pengadilan negeri maupun pengadilan tata usaha negara.

Berdasarkan kajian terhadap literatur di atas, hingga saat ini penelitian mengenai implementasi hak servituut hanya dilakukan dengan menggunakan metode studi pustaka dan studi kasus terhadap suatu putusan pengadilan atau sengketa yang terjadi. Penelitian mengenai kondisi atau fenomena yang terjadi di lapangan terkait implementasi hak servituut belum banyak dilakukan sehingga permasalahan yang terjadi di kalangan masyarakat tidak terekspos secara jelas. Kajiankajian mengenai permasalahan terkait penerapan hak servituut perlu banyak dilakukan sebagai suatu bahan masukan perihal urgensi pembentukan peraturan perundang-undangan terkait teknis pelaksanaan asas fungsi sosial berupa akses jalan yang timbul dari hak servituut.

Penelitian ini dilaksanakan untuk memahami implementasi hak servituut sebagai aktualisasi dari asas fungsi sosial atas tanah. Secara mendetail tujuan dari penelitian ini untuk mengkaji apa saja yang menjadi dasar penerapan kebijakan hak servituut di Kantor Pertanahan Kabupaten Bekasi. Selain itu juga sebagai tinjauan hukum terhadap kebijakan hak servituut pada kegiatan PTSL yang dilaksanakan oleh Panitia Ajudikasi PTSL Kantor Pertanahan Kabupaten Bekasi.

\section{B. Metode}

Penelitian ini dilaksanakan dengan menggunakan metode penelitian hukum empiris. Penelitian ini bertujuan untuk memperoleh pemahaman yang mendalam terhadap konsepsi asas fungsi sosial hak atas tanah melalui penerapan kebijakan hak servituut, juga mengkaji implementasinya sebagai upaya pencegahan sengketa dan konflik pertanahan yang terkait dengan akses jalan. Penelitian ini berfokus pada jalan lingkungan yang terbentuk dari hasil pelaksanaan hak servituut oleh masyarakat, namun telah diselenggarakan pengerasan jalan oleh pemerintah daerah dan secara faktual telah difungsikan sebagai jalan umum. Peneliti memilih Desa Lambangjaya, Kecamatan Tambun Selatan, Kabupaten Bekasi sebagai lokasi untuk melakukan penelitian.

Adapun teknik pengumpulan data dilakukan melalui wawancara dengan informan yang terkait yaitu Panitia Ajudikasi PTSL, Perangkat Desa Lambangjaya dan masyarakat yang terlibat dalam kegiatan PTSL; observasi langsung di lapangan guna memperoleh data secara langsung berupa tahapan implementasi hak servituut di Kantor Pertanahan Kabupaten Bekasi sehingga dapat diketahui kesesuaian pelaksanaan dengan peraturannya; dan studi dokumen dan peraturan perundangan yang terkait.

\section{Penerapan Kebijakan Hak Servituut}

Pada ketentuan Hukum Adat mengenai tanah, akses jalan terhadap sebuah bidang tanah yang terhalang statusnya berupa izin melintas yang diberikan pemilik bidang tanah lain yang memiliki akses ke jalan umum. Selain Hukum Adat teknis penyelenggaraan jalan antar bidang tanah pekarangan pernah diatur dalam Pasal 674 sampai dengan Pasal 710 KUHPerdata tentang hak servituut, namun telah dicabut dan dinyatakan tidak berlaku dengan terbitnya UUPA.

Pada ketentuan Konversi Pasal 1 butir 6 UUPA masih ditemukan pengaturan mengenai beberapa jenis pembebanan hak, termasuk hak servituut tetap membebani hak milik dan hak guna bangunan yang dibebaninya itu. Arti daripada Konversi ini menurut Parlindungan (1999) adalah penyesuaian hak-hak lama yang tunduk pada KUHPerdata dan aturan Hukum Adat untuk dapat 
masuk dalam suatu sistem menurut UUPA. Kendati demikian, sampai saat ini belum terbit peraturan mengenai bagaimana mekanisme penerapan hak servituut sebagai suatu asas fungsi sosial hak atas tanah dalam sistem pendaftaran tanah di Indonesia. Oleh sebab itu, ketentuan hak melewati pekarangan orang lain menurut Hukum Adat itu sendiri, berdasarkan beberapa yurisprudensi menyatakan bahwa penyelenggaraan jalan antar tanah pekarangan sebagai perwujudan suatu fungsi sosial hak atas tanah saat ini pelaksanaannya ditafsirkan sama dengan mekanisme penyelenggaraan hak servituut menurut KUHPerdata (Fitria, 2014 dan Wirandhana, 2017).

Penerapan hukum adat dan ketentuan hak servituut yang membebani bidang tanah pekarangan menurut KUHPerdata, dalam kenyataannya tidak dapat begitu saja dapat diterapkan dalam pelaksanaan penerbitan suatu hak atas tanah (khususnya Hak Milik). Untuk itu perlu dirumuskan suatu kebijakan sebagai langkah konkret dalam penerapan kedua aturan tersebut. Sebagaimana suatu kebijakan, maka rumusan dan penerapannya dapat berbeda-beda di setiap daerah. Termasuk kebijakan perihal hak servituut yang dilaksanakan di Kantor Pertanahan Kabupaten Bekasi dalam pelaksanaan pendaftaran tanah dapat berbeda implementasinya dengan kantor pertanahan yang lain. Berikut beberapa hal yang melatarbelakangi penerapan kebijakan hak servituut dalam di Kantor Pertanahan Kabupaten Bekasi, berdasarkan gambaran kondisi pada lingkungan penelitian di Desa Lambangjaya.

\section{Status Jalan yang Timbul dari Pelaksanaan Hak Servituut}

Tidak semua masyarakat di Kabupaten Bekasi mengenal atau akrab dengan istilah hak servituut, namun berdasarkan jiwa sosial, nilai agama dan nilai-nilai adat, para pemilik tanah tersebut berkenan sebagian tanahnya digunakan untuk jalan bagi bidang tanah yang terhalang. Dalam praktiknya terdapat dua mekanisme penyelenggaraan suatu jalan dari hak servituut oleh para pemilik tanah di Desa Lambangjaya, yaitu sebagai berikut:

a) Hak atas tanahnya dilepaskan/diserahkan.

Pada kategori ini, para pemilik tanah rela untuk sepenuhnya melepaskan/menyerahkan sebagian bidang tanahnya digunakan untuk jalan. Para pemilik tanah tidak berkeberatan melepaskan tanahnya itu demi menjunjung norma hukum adat yang dapat memberikan kemudahan bagi masyarakat lain. Kendati penyerahan sebagian hak untuk jalan itu secara fisik dapat terwujud dengan baik di lapangan, namun pengadministrasian perihal penyerahan haknya belum dilaksanakan secara seksama. Penyerahan hak untuk jalan dilaksanakan hanya dalam suatu ikrar lisan oleh pemiliknya.

b) Hak atas tanahnya tidak dilepaskan/diserahkan.

Pada sisi lain terdapat pemilik tanah yang tidak berkeberatan sebagian tanahnya dijadikan jalan, namun enggan menyerahkan sebagian hak atas tanahnya itu untuk menjadi fasilitas umum. Alasan pemilik tanah mempertahankan haknya karena berasumsi bahwa dengan menyerahkan sebagian hak atas tanahnya menjadi jalan akan menghilangkan sebagian nilai ekonomi apabila di kemudian hari dilakukan transaksi jual beli atau berkurangnya nilai ganti kerugian saat terkena pengadaan tanah untuk kepentingan umum. Para pemilik tanah pada kategori ini bahkan enggan mendaftarkan tanahnya apabila ukuran tanah dalam sertipikat tidak mengikutsertakan luas bidang tanah yang menjadi jalan, sehingga dalam membuktikan kepemilikan tanahnya cukup menggunakan lembaga Letter $\mathrm{C}$ dan/atau surat di bawah tangan saja. 
Terhadap pemilik tanah yang setuju menyerahkan haknya menjadi jalan umum tentunya kebijakan ini tidak menjadi kendala, sementara terhadap pemilik tanah yang tidak melepaskan hak atas tanahnya namun pembangunan jalannya telah dilaksanakan menggunakan anggaran negara dapat menyebabkan dualisme status jalan. Apabila benturan kepentingan tidak terhindarkan, dapat memicu terjadinya konflik di kemudian hari. Penyelesaian permasalahan perihal status akses jalan harus dapat terselesaikan dan dipastikan sebelum pelaksanaan pendaftaran hak atas tanahnya.

2. Pengembangan wilayah dan pembebasan tanah

Berdasarkan Peraturan Daerah Nomor 12 Tahun 2011 tentang Rencana Tata Ruang Wilayah (RTRW) Kabupaten Bekasi Tahun 2011-2031, Desa Lambangjaya termasuk salah satu desa yang menjadi Wilayah Pengembangan (WP) I di Kabupaten Bekasi. Pertumbuhan dan perkembangan wilayah di Desa Lambangjaya cukup pesat, terutama pengembangan wilayah untuk kawasan permukiman. Pada luas keseluruhan wilayah Desa sebagian besar wilayahnya merupakan tanah yang telah dikuasai oleh perusahaan PT Putra Alvita Pratama, selaku pengembang kawasan Perumahan Grand Wisata Residence. Keberadaan jalan tentunya sangat penting untuk mobilitas masyarakat, sehingga saat sebagian besar tanah telah dibebaskan oleh perusahaan dan dilakukan pembangunan, jangan sampai masyarakat tidak mendapat keadilan perihal akses jalan.

Penyediaan akses jalan dan larangan mengurung bidang tanah lain, merupakan kewajiban pada suatu penguasaan tanah oleh perusahaan pengembang pemegang HGB. Hal itu tersurat dalam Pertimbangan Teknis Pertanahan dalam rangka pengajuan Izin Lokasi, hingga dalam SK Pemberian Hak untuk penerbitan HGB-nya. Salah satu poin dalam Risalah Pertimbangan Teknis Pertanahan dalam rangka persetujuan atau penolakan Izin Lokasi disebutkan larangan menutup akses jalan masyarakat serta kewajiban untuk membangun, memelihara dan meningkatkan kualitas akses jalan yang telah ada. Aturan yang berkenaan dengan hal tersebut terdapat dalam Pasal 8 Permen ATR/KBPN Nomor 15 Tahun 2018 tentang Pertimbangan Teknis Pertanahan jo. PP Nomor 16 Tahun 2004 tentang Penatagunaan Tanah jo. Pasal 43 PP Nomor 18 Tahun 2021 tentang Hak Pengelolaan, Hak Atas Tanah, Satuan Rumah Susun dan Pendaftaran Tanah.

Keberadaan suatu jalan haruslah memiliki suatu kepastian dan kejelasan mengingat pentingnya jalan dalam menyokong segala kepentingan masyarakat dalam menjalani kehidupan sehari-hari. Adanya penyerahan hak masyarakat untuk jalan yang kemudian dijadikan aset pemerintah, dapat membuat penyelenggaraannya dilakukan dengan lebih baik melalui anggaran negara. Apabila perusahaan memerlukan tanah termasuk jalan yang ada, maka pemerintah dapat menuntut ganti kerugian berupa ruis/ag/tukar guling dengan pembangunan jalan yang sepadan dengan yang telah dibangun oleh pemerintah, sehingga masyarakat tidak akan kehilangan haknya atas akses jalan.

\section{Nilai Tanah}

Menurut informasi Zona Nilai Tanah (ZNT) yang diperoleh dari Kantor Pertanahan Kabupaten Bekasi, pada tahun 2021, Desa Lambangjaya memiliki Nilai Tanah berkisar antara Rp.500.000 Rp.1.000.000 per meter persegi. Peningkatan nilai tanah yang kian tinggi menyebabkan kemampuan negara dalam melakukan pengadaan tanah untuk jalan semakin sulit, sementara kebutuhan akses jalan tidak dapat ditunda. Untuk itu asas gotong royong dalam penyediaan jalan dapat menjadi 
solusi, masyarakat menyediakan tanah untuk jalan dan pemerintah menyelenggarakan pembangunan jalannya. Hal itu bisa dijadikan win-win solution bagi kedua belah pihak.

Berdasarkan pemaparan di atas, maka terhadap penyelenggaraan jalan yang timbul dari hak servituut sebagai suatu aspek fungsi sosial hak atas tanah haruslah diperhatikan dalam Penerbitan Sertipikat Hak Atas Tanah (SHAT), demi terwujudnya keadilan bagi seluruh masyarakat. Kebijakan hak servituut yang diterapkan di Kantor Pertanahan Kabupaten Bekasi yang menuntut pelepasan sebagian hak atas tanah untuk jalan merupakan suatu upaya penyelarasan lembaga pendaftaran tanah dengan norma adat, norma sosial dan penyelenggaraan penataan ruang oleh pemerintah daerah. Selain sebagai pemenuhan asas kepastian hukum, juga menjunjung nilai-nilai kemanfaatan hukumnya atas pentingnya kepastian status jalan dalam kehidupan bermasyarakat dan penataan ruang, sebagai suatu antisipasi atas sengketa dan konflik pertanahan terkait akses jalan di kemudian hari.

\section{Implementasi Kebijakan Hak Servituut Pada Pelaksanaan PTSL}

\section{Pelaksanaan Kebijakan Hak Servituut Pada Data Fisik Bidang Tanah}

Memperhatikan ketentuan Hak Servituut menurut KUHPerdata dan hak melewati tanah orang lain yang berasal dari Hukum Adat, secara esensi merupakan beban kepada suatu bidang tanah untuk memberikan akses kepada bidang tanah yang terhalang olehnya. Konteks dari beban tersebut adalah dalam penggunaan dan pemanfaatan tanah yaitu suatu hak atas tanah selain untuk kepentingan pemiliknya dalam penggunaannya perlu adanya batasan-batasan dengan memperhatikan aspek sosial dan nilai kemanfaatan untuk umum. Harsono (2008) menyatakan bahwa fungsi sosial pada tanah adalah suatu pembatasan atas hak atas tanah, baik terhadap hak primer atau hak sekunder. Tanah-tanah tersebut boleh digunakan sebebas-bebasnya tetapi tidak boleh merugikan kepentingan umum sekitarnya. Pembatasan tersebut sekiranya dapat menciptakan keseimbangan, kemakmuran, keadilan dan kesejahteraan bagi masyarakat maupun pemilik tanah.

Implikasi dari ketentuan pelaksanaan pembatasan hak untuk memperhatikan fungsi sosial dalam sistem pendaftaran tanah di Indonesia sebenarnya telah diwujudkan. Ketentuan itu berupa pembatasan penggunaan hak oleh pemilik tanah yang harus memperhatikan kepentingan masyarakat luas. Selain pembatasan untuk penyediaan akses jalan, pembatasan-pembatasan itu juga menyangkut saluran air, sempadan sungai, garis sempadan pantai dan pembatasan penggunaan dalam kawasan lindung. Pembatasan penggunaan hak itu dicantumkan ketika dilakukan pembukuan haknya. Ketentuan tersebut sesuai dengan Pasal 68 dan Pasal 90 Peraturan Menteri Negara Agraria/Kepala Badan Pertanahan Nasional Nomor 3 Tahun 1997 (PMNA/KBPN Nomor 3 Tahun 1997) jo. Pasal 28 Peraturan Menteri Agraria dan Tata Ruang/Kepala Badan Pertanahan Nasional Nomor 6 Tahun 2018 (Permen ATR/KBPN Nomor 6 Tahun 2018).

Pencatatan pembatasan penggunaan tanah dicantumkan dalam Buku Tanah Sertipikat Hak Atas Tanahnya. Adanya catatan pembatasan itu, pendaftaran tanah tidak menghilangkan hak atas tanah pemiliknya, namun tidak juga menghilangkan hak pihak lain untuk dapat lewat menuju bidang tanahnya. Konsep tersebut menyeimbangkan antara hak dan kewajiban pemilik tanah berdasarkan asas fungsi sosial dapat terpenuhi. Selama mekanisme tersebut dilakukan secara konsisten oleh 
setiap Kantor Pertanahan sebenarnya dapat mengantisipasi potensi sengketa terkait akses jalan. Pemegang sertipikat hak atas tanah dapat mengetahui batas hak atas tanahnya dan sejauh mana tanah tersebut dapat digunakan, sehingga pemilik tanah sadar kewajibannya tanpa harus kehilangan sebagian hak atas tanahnya.

Hasil penelitian menunjukkan bahwa hak servituut yang saat ini dilaksanakan di Kantor Pertanahan Kabupaten Bekasi berbeda dengan konsep menurut Hukum Adat dan KUHPerdata. Berdasarkan contoh yang dilaksanakan oleh Panitia Ajudikasi PTSL, pembatasan hak atas tanah telah mengalami pergeseran makna. Pelaksanaannya bukan lagi berupa pencatatan pembatasan penggunaan tanah yang dimuat pada Buku Tanah dan Sertipikat Hak Atas Tanah, namun bergeser menjadi konsep fungsi sosial yang menuntut agar sebagian hak atas tanahnya dilepaskan/diserahkan menjadi jalan sebagai fasilitas umum.

Untuk memperjelas pelaksanaan kebijakan Panitia Ajudikasi PTSL Kantor Pertanahan Kabupaten Bekasi terkait kebijakan hak pengabdian pekarangan dalam produk data fisik bidang tanah dapat digambarkan pada skema di bawah ini.

Gambar 1. Skema Pengumpulan Data Fisik dan Pengkategorian Produk PTSL

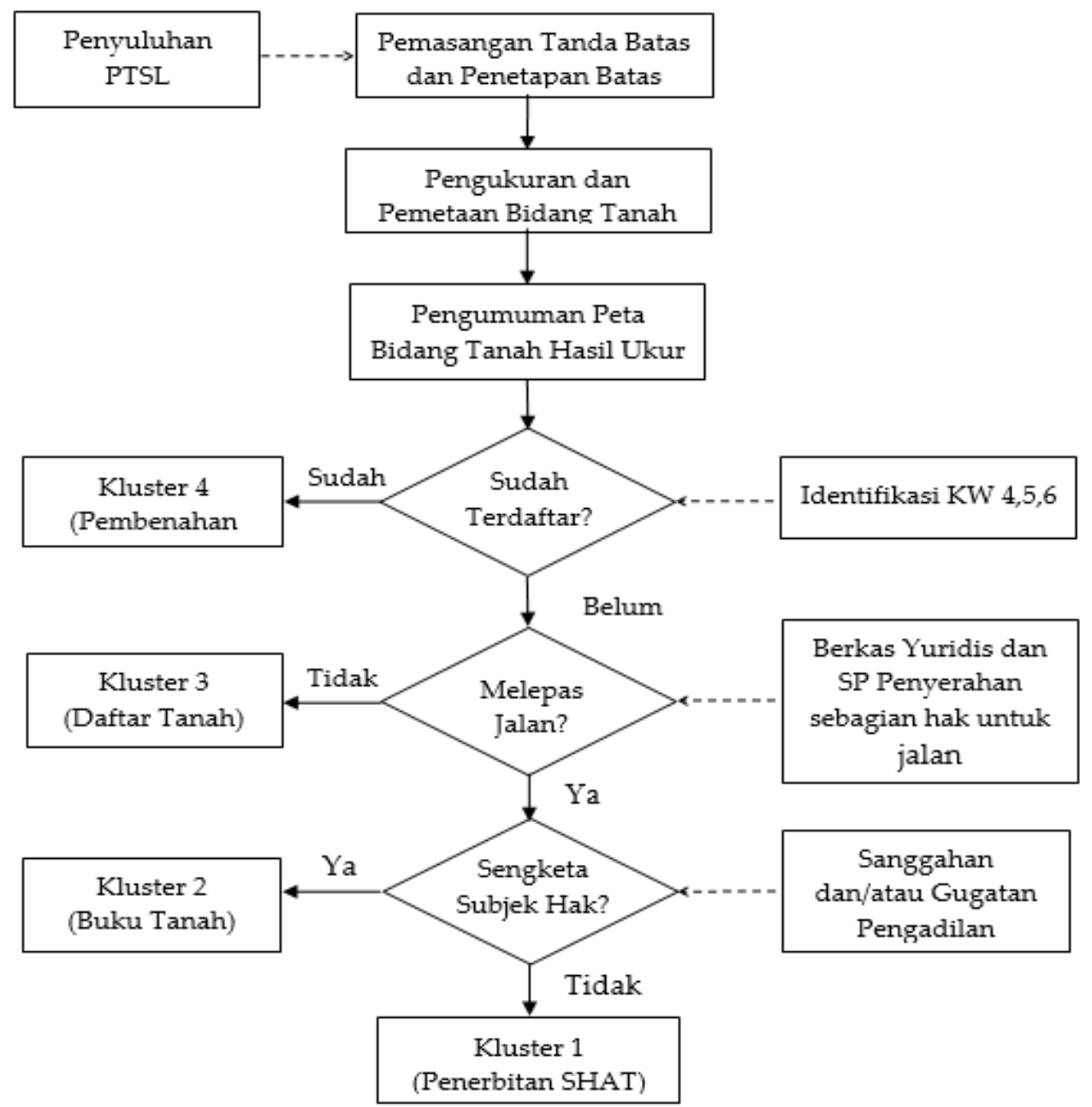

Sumber: Hasil Olahan Peneliti, 2021

Penerapan kebijakan penyerahan hak atas tanah yang telah menjadi jalan diperkenalkan oleh Panitia Ajudikasi PTSL sejak kegiatan penyuluhan kepada komponen pemerintahan Desa beserta 
seluruh elemen masyarakat. Saat penyuluhan berlangsung Panitia Ajudikasi menggunakan pendekatan persuasif mengenai pentingnya akses jalan dalam penerbitan hak atas tanah. Selain sebagai pengamalan asas fungsi sosial hak atas tanah, keberadaan akses jalan ke depannya dapat mendatangkan beberapa manfaat bagi pemilik tanah dan lingkungan sekitar. Hasil dari musyawarah ini adalah terhadap pemilik tanah setuju penyerahan hak atas tanah menjadi jalan, dapat dimasukkan dalam kategori K1 untuk diterbitkan Sertipikat Hak Atas Tanahnya, sedangkan terhadap pihak yang berkeberatan pelaksanaan pendaftaran tanahnya hanya dilakukan sampai tahap pengumpulan data fisik untuk dijadikan produk K3.3 dan dibuat daftar tanah.

Pengumpul Data Fisik Panitia Ajudikasi PTSL dalam pelaksanaan penetapan batas dan saat melaksanakan pengukuran, turut andil dalam memberikan pemahaman mengenai keberadaan jalan yang sudah terbentuk untuk dapat diserahkan menjadi fasilitas umum oleh pemiliknya. Bagi sebagian masyarakat, penjelasan di lapangan lebih dapat lebih diterima dan disetujui karena dapat melihat langsung nilai kemanfaatan dari kejelasan status jalan bila diserahkan menjadi fasilitas umum.

Setelah dilakukan penjelasan terkait asas fungsi sosial namun masih terdapat pemilik tanah yang berkeberatan di lapangan dan tetap menunjukkan batas tanahnya termasuk jalan yang ada, maka petugas ukur mengambil data batas bidang tanah sesuai penunjukan dan juga bentuk jalan yang ada. Ketika hasil ukur bidang tanah hasil pengolahan telah didapat, maka luasan yang diumumkan adalah luasan bidang tanah tanpa mengakomodasi bagian tanah yang telah menjadi jalan. Hal ini dilakukan sesuai hasil musyawarah dan pendekatan persuasif yang dilakukan panitia PTSL saat kegiatan penyuluhan berlangsung. Penting untuk menggambarkan kondisi lapangan sesuai realita (keberadaan akses jalan), sehingga status keberadaan jalan dapat terjamin untuk dapat dipergunakan oleh seluruh pihak baik yang menyerahkan sebagian haknya untuk jalan maupun yang tidak berkenan melakukan penyerahan hak. Selain itu juga mendukung pemerintah daerah dalam pelaksanaan kebijakan penataan ruang wilayahnya.

Berlanjut pada kegiatan pengolahan data ukur dan pemetaan bidang tanah, tahap pertama adalah melakukan pemilahan terhadap bidang yang telah terdaftar namun belum terpetakan secara baik sehingga perlu dilakukan peningkatan kualitas data K4 (KW456). Aspek yang harus dipenuhi dalam peningkatan kualitas data pendaftaran tanah adalah kesesuaian letak, bentuk dan luas. Bidang-bidang tanah yang sudah terdaftar namun belum terpetakan dalam peta pendaftaran tanah, dilakukan identifikasi pada peta hasil ukur bidang tanah kegiatan PTSL berdasarkan daftar K4 (KW456). Keterangan terkait bidang-bidang tanah yang telah terdaftar diperoleh melalui koordinasi dengan pihak Pemerintahan Desa, menghimpun informasi dari masyarakat dan melihat arsip GU, GS/SU dan Buku Tanah yang ada di Kantor Pertanahan Kabupaten Bekasi. Setelah bidang tanah dapat diidentifikasi dengan bentuk dan luas telah sesuai dengan GS/SU dan/atau Buku Tanah, maka bidang tanah tersebut direposisi lalu dilakukan validasi.

Bidang tanah yang belum terdaftar selanjutnya dilakukan pengumuman data fisik, data yuridis dan peta bidang-bidang tanah selama 14 (empat belas) hari kalender di Kantor Panitia Ajudikasi PTSL dan Kantor Kepala Desa Lambangjaya. Pengumuman ini selain untuk memenuhi asas publisitas, juga memberikan kesempatan terhadap pemilik tanah atau pihak-pihak yang berkeberatan dapat melakukan sanggahan. Ketika terdapat keberatan terkait hasil ukur maka panitia akan melakukan 
inventarisasi dan petugas ukur akan melakukan pemeriksaan ulang di lapangan. Setelah pengukuran ulang dilaksanakan Satgas Fisik mengeluarkan PBT revisi yang memuat data fisik hasil pengukuran ulang.

Pada pelaksanaan PTSL di Desa Lambangjaya, pemilik tanah yang belum bersedia mendaftarkan tanahnya dalam kegiatan PTSL, termasuk karena tidak berkenan melepaskan sebagian hak atas tanahnya dijadikan jalan untuk fasilitas umum dengan status tanah negara, berdasarkan Juknis PTSL Nomor 1/Juknis-100.HK.02.01/1/2021 panitia Ajudikasi PTSL akan mengelompokkan bidang tanah tersebut pada Kluster 3.3 (K3.3) dan dibuatkan daftar tanah. Sementara itu, terhadap para pemilik tanah pekarangan yang terkena penerapan kebijakan hak servituut dan setuju untuk melepaskan sebagian haknya menjadi jalan, maka mereka dapat melanjutkan pendaftaran pengakuan haknya dengan melengkapi pemberkasan data yuridis dan pernyataan pelepasan sebagian haknya. Apabila pemberkasan data yuridis telah ditempuh dan semua jenis persyaratan telah dipenuhi, namun ada sanggahan dan/atau gugatan di pengadilan dari pihak lain terkait keberatan subjek hak, maka status pengkategorian bidang dibuat menjadi Kluster 2 (K2). Pembukuan haknya hanya dicatat pada buku tanah saja tanpa mencantumkan nama pemegang haknya. Setelah ada perdamaian atau putusan pengadilan yang berkekuatan hukum tetap perihal subjek yang berhak, Sertipikat Hak Atas Tanahnya dapat diterbitkan atas nama subjek yang berhak tersebut.

Terakhir, apabila objek bidang tanah, subjek hak dan hubungan hukum di antara subjek dengan objek itu telah memenuhi persyaratan dan dapat dibuktikan pada aspek fisik dan yuridisnya, juga tidak ada keberatan dari pihak lain maka pengkategorian bidang tanah seperti ini masuk ke dalam Kluster 1 (K1). Nantinya dilakukan pembukuan hak dan dapat diterbitkan Sertipikat Hak Milik (SHM) kepada pemilik tanah selaku pemegang hak. Dengan terbitnya SHM yang telah mencantumkan gambar jalan pada Surat Ukurnya, maka hal ini menjadi jaminan kepastian hukum yang kuat baik dari aspek bukti kepemilikan bidang tanah oleh pemegang hak, juga menjadi perlindungan terhadap status jalan untuk kepentingan umum. Hal ini menggambarkan aspek hak milik atas tanah selain melindungi kepentingan pribadi juga memberikan keadilan bagi masyarakat luas untuk melakukan aktivitas di atas tanahnya tanpa khawatir terjadi penutupan jalan.

Sebagaimana yang telah dipaparkan perihal kebijakan hak servituut dalam kegiatan PTSL di Desa Lambangjaya, terkait data fisik kebijakan itu dilaksanakan secara terstruktur dari mulai pengumpulan data fisik hingga penerbitan produk spasial PTSL. Kebijakan ini apabila kemudian dikaitkan dengan hak keperdataan seseorang, mengurangi atau memotong luas bidang tanah seseorang karena sebagian telah menjadi jalan tanpa seizin pemiliknya dapat dipandang sebagai tindakan penghilangan hak orang lain. Kebijakan tersebut meskipun pelaksanaannya didasarkan atas dasar kemanfaatan hukum, namun apabila tidak disertai pelaksanaan yang sesuai dengan kaidah hukum yang berlaku, maka hanya akan menjerat diri pribadi petugas ukur berikut Panitia Ajudikasi PTSL karena dianggap telah melakukan tindakan yang melanggar hak keperdataan seseorang.

Musyawarah yang telah dilaksanakan dalam penyuluhan PTSL, perihal status jalan untuk diserahkan menjadi fasilitas umum memang telah dilaksanakan, namun selain pihak yang mayoritas setuju terdapat juga pihak minoritas yang tidak setuju perihal penyerahan itu. Terhadap para 
pemilik tanah yang tidak setuju atas kebijakan penyerahan hak untuk jalan, bersedia tidak mendapatkan fasilitas penerbitan hak atas tanahnya dan kooperatif apabila produk pendaftaran tanahnya hanya sebatas K3 dan pencatatan dalam daftar tanah. Sehingga terhadap keputusan mereka harus juga dihormati sebagai bagian dari musyawarah yang demokratis. Petugas Ukur dalam kegiatan penetapan batas dapat menyelaraskan antara kebijakan hak servituut, keputusan pihak yang menyetujui penyerahan hak dan prinsip para pihak yang berkeberatan melakukan penyerahan hak. Petugas ukur dapat memilah mana pihak yang setuju dan tidak setuju pelaksanaan penyerahan hak itu di lapangan. Para pemilik tanah yang setuju tentunya tidak akan berkeberatan apabila bidang tanahnya dikurangi karena sebagian tanahnya telah dijadikan jalan dan ditetapkan batas bidang tanahnya berbatasan langsung dengan jalan.

Pemilik tanah yang berkeberatan menyerahkan hak, akan menjadikan permasalahan baru ketika hak atas tanahnya tetap dikurangi dalam penerbitan Peta Bidang Tanah (PBT) dan daftar tanah, karena tidak sesuai dengan penunjukan oleh pemilik dan juga tidak ditempuh lembaga penyerahan hak untuk jalan. Pada kasus ini petugas ukur dapat mengakomodasi batas-batas bidang sesuai batas yang ditunjukkan oleh pemilik tanah, namun perlu dicatat bahwa bidang tanah tersebut dimasukkan pada kategori K3.3, sehingga dalam pengolahan data ukur dan penerbitan PBT dapat mengakomodasi seluruh bidang tanah yang pemiliknya berkeberatan tanpa dilanggar hak keperdataannya. Pelaksanaannya dapat dibuat PBT yang menggambarkan bidang tanah sesuai penunjukan, namun di atasnya dibuat garis putus-putus yang menggambarkan keberadaan jalan. Seluruh masyarakat kemudian dapat mengerti bahwa bidang tanah yang tidak melepaskan hak atas tanahnya tetap didaftarkan tanahnya menjadi K3.3 dan daftar tanah. Apabila kemudian pihak yang berkeberatan tersebut ingin diterbitkan sertipikat hak atas tanahnya, maka harus dilakukan pengukuran ulang yang kemudian "memotong" bagian yang telah dipergunakan untuk jalan. Hal tersebut sebagai bentuk pelaksanaan norma sosial terhadap para pihak yang sudah menyerahkan sebagian hak atas tanahnya untuk jalan.

Pelaksanaan demikian kiranya dapat menjadi jalan tengah bagi semua pihak. Bagi Panitia PTSL kebijakannya dapat terlaksana. Bagi pihak yang setuju menyerahkan hak untuk jalan selain memberikan kemanfaatan bagi seluruh masyarakat juga bisa diterbitkan SHAT-nya sebagai suatu jaminan kepastian hukum. Kemudian bagi yang berkeberatan tetap bisa dilakukan pendaftaran dalam K3.3 tanpa merasa sebagian hak atas tanahnya dihilangkan. Dengan begitu kebijakan tersebut selain menjunjung nilai kemanfaatan bagi masyarakat luas, tentunya juga akan lebih berkeadilan bagi semua pihak tanpa adanya pelanggaran hak keperdataan.

\section{Pelaksanaan Kebijakan Hak Servituut Pada Data Yuridis}

Kebijakan yang diambil terkait hak servituut di Kabupaten Bekasi sepintas bertentangan dengan hak keperdataan yang melekat pada seseorang atas sesuatu yang dihakinya. Merujuk pada makna hak keperdataan itu sendiri adalah hanya menyangkut bagaimana hubungan hukum antara subjek hak dengan objek hak itu terjadi. Asas dan cara terjadinya hubungan hukum dalam konteks pembuktian itulah yang dilindungi oleh KUHPerdata. Saat paradigma hak keperdataan itu disandingkan dengan kebijakan pembatasan hak dalam suatu pendaftaran tanah, hal tersebut dapat menjadi anggapan bahwa Panitia Ajudikasi PTSL Kantor Pertanahan Kabupaten Bekasi telah melakukan perbuatan melawan hukum dengan menghilangkan sebagian hak pemilik tanah dengan 
mengurangi bagian yang telah menjadi jalan. Padahal pembatasan yang dilakukan bukan suatu pemaksaan kehendak egois Pemerintah kepada masyarakatnya, namun semua itu demi kepentingan masyarakat yang lebih luas.

Menurut Agustina (2003), dalam menentukan suatu perbuatan dapat dikualifisir sebagai melawan hukum, diperlukan 4 syarat yaitu; (1) Bertentangan dengan kewajiban hukum si pelaku, (2) Bertentangan dengan hak subjektif orang lain, (3) Bertentangan dengan kesusilaan dan kaidah moral, dan (4) Bertentangan dengan kepatutan, ketelitian dan kehati-hatian untuk memperhatikan kepentingan orang lain. Melihat syarat-syarat perbuatan melawan hukum tersebut, dimana asas kesosialan dan kepentingan umum lebih diutamakan terlebih adanya musyawarah yang dilakukan secara terbuka, maka kebijakan perihal kewajiban menyerahkan sebagian hak atas tanah untuk jalan yang diambil oleh Panitia Ajudikasi PTSL Kantor Pertanahan Kabupaten Bekasi bukan merupakan suatu perbuatan melawan hukum.

Dalam rangka menghormati hak keperdataan subjek hak dan itikad baiknya menyerahkan sebagian hak atas tanahnya demi fasilitas umum dan tertib pengadministrasian dalam pembuatan Warkah pertanahan, sehingga perlu dibuatkan suatu pencatatan yang menerangkan perihal penyerahan hak itu sebagai suatu perbuatan yang sah dan berkepastian hukum oleh pemilik tanah dalam melepaskan sebagian hak keperdataannya. Sehingga setelah penyerahan itu dibuat, status tanah yang diserahkan itu kemudian berubah menjadi tanah negara.

Pernyataan penyerahan sebagian hak itu dalam pelaksanaannya dibuat dalam Surat Pernyataan Atas Batas Tanah dan Luas Tanah. Surat pernyataan ini telah disediakan oleh Panitia Ajudikasi PTSL dalam bentuk formulir yang berisi perihal identitas pemilik, keterangan tentang bidang tanah dan tiga poin yang menyatakan persetujuan pemilik tanah, yaitu: (1) Pernyataan tentang pemasangan tanda batas yang telah sesuai dengan PMNA/KBPN Nomor 3 Tahun 1997, (2) Pernyataan mengenai terpenuhinya asas kontradiktur delimitasi, dan (3) Pernyataan pemilik tanah menerima hasil ukur yang dikeluarkan oleh petugas ukur, baik hasilnya lebih kecil maupun lebih besar dari luas yang tertera pada alas hak yang dimiliki pemilik tanah.

Terkait pelepasan sebagian hak atas tanahnya, pada bagian bidang tanah yang berbatasan dengan sebagian yang diserahkan haknya dituliskan menjadi berbatasan dengan jalan. Surat pernyataan ini dinyatakan sah apabila telah ditandatangani di atas materai oleh pemilik tanah, dibubuhi tanda tangan persetujuan pemilik bidang tanah berbatasan yang lain, kemudian ditandatangani dan dicap/stempel oleh pejabat RT setempat sebagai pihak yang mengetahui surat pernyataan tersebut. Dengan kerelaannya Pemohon melepas sebagian hak atas tanahnya untuk jalan maka pembatasan penggunaan hak untuk penyediaan jalan sudah tidak perlu dilakukan pencatatannya lagi, baik dalam pertimbangan Panitia Ajudikasi PTSL pada Risalah Penelitian Data Yuridis (DI 201) maupun dalam pembukuan hak dan penerbitan Sertipikat Hak Atsa Tanahnya.

Secara praktis, pelaksanaan kebijakan hak servituut yang diambil oleh Panitia Ajudikasi PTSL dapat terlaksana dengan baik di lapangan. Perihal pengumpulan dan pengolahan data fisik secara jelas dapat dilakukan tanpa mengalami kendala yang berarti, akan tetapi dengan melihat dokumen yang ada pengadministrasian penyerahan hak sebagai data yuridisnya itu belum terlaksana dengan baik. Penggunaan surat pernyataan kiranya belum memenuhi kaidah penyerahan hak yang dipersyaratkan. Ketentuan pada Pasal 131 Ayat (3) PMNA/KBPN Nomor 3 Tahun 1997 mengatur 
perihal pendaftaran hapusnya suatu hak, namun dalam isi pasal tersebut juga didapati aturan mekanisme pelaksanaan pelepasan hak. Suatu pelepasan/penyerahan hak dapat ditempuh dengan suatu akta notaris, surat pelepasan/penyerahan hak yang dibuat di hadapan dan disaksikan Camat letak tanah atau surat pelepasan/penyerahan hak yang dibuat di depan dan disaksikan oleh kepala Kantor Pertanahan.

Memperhatikan ketentuan-ketentuan yang ada perihal penyerahan hak atau pelepasan hak pada dasarnya hanya berlaku pada suatu jenis hak yang telah terbit berdasarkan ketentuan UUPA, akan tetapi dalam kenyataannya di lapangan meskipun belum terbit hak atas tanahnya para pemilik telah memiliki tanah itu dalam bentuk suatu hak keperdataan. Status tanah masyarakat di Desa Lambangjaya merupakan Tanah Bekas Milik Adat, yang disebut masyarakat dengan istilah tanah girik. Tanah Bekas Milik Adat merupakan tanah adat atau tanah-tanah lain yang belum dikonversi menjadi salah satu tanah dengan hak tertentu (Hak Milik, HGB, HP atau HGU) dan belum didaftarkan atau disertifikatkan pada Kantor Pertanahan setempat (Purnamasari, 2014). Lembaga konversi mengakui hak yang dulu timbul dalam peraturan adat untuk diakomodasi sesuai ketentuan dalam UUPA, maka tata cara pendaftarannya dilakukan melalui lembaga konversi, yaitu Penegasan Hak atau Pengakuan Hak. Seyogyanya pada lembaga tersebut tidak dapat dilakukan suatu pembatasan hak atas tanah, hanya pembatasan penggunaannya saja.

Melihat realita yang ada, bahwa jalan yang timbul dari hak servituut telah digunakan secara terus-menerus dalam waktu yang lama dan telah dilakukan pengerasan jalan oleh pemerintah, namun tidak dilaksanakan pengadministrasian perolehan tanahnya secara tertib oleh pemerintah. Hal tersebut menimbulkan dualisme persepsi terhadap status hak atas tanah yang telah menjadi jalan tersebut. Pada satu sisi, secara keperdataan tanah tersebut masih merupakan hak dari pemiliknya yang masuk dalam alas hak yang dimilikinya, sedangkan di sisi lainnya fisik sebagian tanah para pemilik telah dikuasai pemerintah dalam bentuk pembangunan jalan untuk kepentingan umum.

Menindaklanjuti hal tersebut diperlukan suatu penyerahan hak atas tanah guna memutus hubungan keperdataan antara pemilik tanah dengan tanahnya. Penyerahan ini dimaksudkan untuk menyerahkan sebagian hak keperdataan dari suatu hak atas tanah yang dimiliki subjek hak yang dibuktikan melalui alas hak. Hal tersebut sebagai suatu perwujudan dari asas fungsi sosial atas tanah yang didahului dari pelaksanaan beban hak servituut. Bagian tanah yang tidak diserahkan untuk dapat didaftarkan haknya menurut UUPA, menggunakan alas hak yang ada. Penyerahan hak ini juga berfungsi ketika terjadi peralihan hak atas tanah sebagian jalan yang berasal dari subjek hak sebelumnya tidak ikut beralih kepada subjek hak yang baru.

Kaitannya dengan kebijakan hak servituut terhadap sebagian bidang tanah untuk diserahkan menjadi fasilitas umum dengan status tanah negara, karena Sertipikat Hak Atas Tanah mempunyai dua sisi fungsi, yaitu sebagai alat bukti kepemilikan dalam sisi keperdataan dan merupakan bentuk keputusan yang bersifat penetapan (beschikking) yang diterbitkan oleh kepala kantor pertanahan sebagai pejabat tata usaha negara, yang dalam PTSL dilimpahkan kepada Ketua Panitia Ajudikasi PTSL. Sifat dari SHAT sebagai beschikking adalah pengakuan hak milik atas tanah bagi pemiliknya. Sedangkan SHAT bersifat deklaratoir, karena merupakan keputusan untuk mengakui suatu yang telah ada dan diberikan karena telah memenuhi syarat yang ditentukan sebagai perwujudan dari 
ketentuan peraturan perundang-undangan yang bersifat abstrak menjadi suatu peristiwa konkret (Guntur et al., 2009).

SHAT sebagai suatu keputusan yang diterbitkan oleh Panitia Ajudikasi PTSL tentunya harus tidak bertentangan dengan ketentuan peraturan perundang-undangan dan tidak bertentangan dengan hak-hak keperdataan yang melekat pada seseorang. Kebijakan penyerahan hak atas tanah yang telah dibangun jalan menggunakan anggaran negara, semata-mata juga demi penyelarasan aturan pertanahan dengan aturan penyelenggaraan jalan dan kebijakan pemerintah daerah terkait penataan ruang, akibat secara administrasi penyerahan hak atas tanahnya belum terlaksana ketika pembangunan jalan, namun secara fisik jalan itu telah berwujud menjadi suatu fakta yang tidak dapat dipungkiri.

Dengan demikian dapat dipahami bahwa surat pernyataan penyerahan bertujuan sebagai penyelaras antara hak keperdataan, realitas fasilitas umum yang melekat pada suatu bidang tanah, aturan penataan ruang dan penyelenggaraan pendaftaran tanah agar tidak menimbulkan konflik di kemudian hari. Syarat suatu surat pernyataan penyerahan hak secara jelas telah dikemukakan sebelumnya di atas, tetapi apabila diperhatikan isi dalam surat Pernyataan Atas Batas Tanah dan Luas Tanah, tidak menyinggung suatu makna pelepasan/penyerahan sebagian hak atas tanah untuk kepentingan umum. Surat pernyataan yang dibuat sama sekali tidak mencerminkan adanya penyerahan hak oleh pemilik tanah. Adapun pernyataan kekurangan luas, tidak semua kekurangan luas antara luas yang tertera pada alas hak dengan luas hasil ukur terjadi akibat penyerahan hak. Dapat saja perbedaan luas akibat luas yang dicantumkan pada alas hak didapatkan dengan perkiraan atau pengukuran yang tidak sesuai kaidah kadastral, sementara luas hasil ukur yang terbit dari hasil pengukuran dalam kegiatan pendaftaran tanah oleh petugas ukur merupakan hasil yang telah memenuhi kaidah pengukuran kadastral.

Berdasarkan pemaparan di atas, penggunaan surat pernyataan sebagai dokumen penyerahan hak dimaksudkan sebagai suatu diskresi dalam pelaksanaan PTSL. Penggunaannya karena sebagian bidang tanah masyarakat telah digunakan sebagai jalan dan penyelenggaraannya dilakukan oleh pemerintah daerah menggunakan anggaran negara, sementara pengadministrasiannya belum dilaksanakan. Apabila penyerahan itu harus dilakukan secara mandiri oleh masyarakat akan menimbulkan beban berupa pembiayaan dalam membuat dokumen penyerahan haknya, sementara pemilik tanah tidak diberikan ganti kerugian saat tanahnya digunakan untuk fasilitas umum.

Surat pernyataan penyerahan hak tidak perlu dilakukan diskresi lagi. Pasal 131 PMNA/KBPN Nomor 3 Tahun 1997 telah dengan tegas menyebutkan mekanisme pelepasan/penyerahan untuk dilakukan melalui Akta Pelepasan Hak yang dibuat oleh Notaris, surat pernyataan pelepasan hak yang dibuat dan disaksikan oleh camat atau surat pernyataan pelepasan hak yang dibuat di hadapan Kepala kantor Pertanahan. Adapun bila tetap harus dibuatnya suatu diskresi, maka yang berhak membuat adalah Menteri ATR/KBPN sebagaimana yang diamanatkan pada Pasal 100 PP Nomor 18 Tahun 2019, bukan sebatas pada tingkat Kantor Pertanahan saja.

Seperti yang dikemukakan oleh Mujiburohman (2016) penerapan asas diskresi dibuat karena ketidakmungkinan suatu peraturan perundang-undangan mengatur berbagai dimensi kasus dalam praktik kehidupan sehari-hari. Perkembangan suatu permasalahan dalam kehidupan bermasyarakat 
lebih cepat dibandingkan perkembangan hukum, sehingga aparat pemerintah perlu melakukan kebebasan bertindak guna mengatasi persoalan-persoalan kongkret di kehidupan masyarakat, dalam hal peraturan perudang-undangan tidak mengatur, tidak lengkap atau tidak jelas. Surat Pernyataan Atas Batas Tanah dan Luas Tanah yang saat ini digunakan tidak dikaitkan dengan pernyataan penyerahan hak. Di samping isinya yang tidak menyinggung perihal pernyataan pihak pemilik melepaskan sebagian hak atas tanahnya, juga sudah ada aturan yang jelas bagaimana mekanisme pelepasan/penyerahan hak itu harus dibuat.

Tanpa ditempuhnya penyerahan hak melalui lembaga yang telah ditentukan dalam Pasal 131 PMNA/KBPN Nomor 3 Tahun 1997, secara normatif penyerahan hak itu tidak sah. Status tanahnya tidak menjadi tanah negara walaupun secara faktual bagian tanah tersebut sudah menjadi jalan dan tidak diakomodasi dalam sertipikat hak atas tanah. Tanah tersebut dalam konteks yuridis formal masih menjadi bagian hak keperdataan dari pemilik tanah yang melaksanakan hak servituut. Tidak terpenuhinya mekanisme penyerahan hak yang sesuai dengan ketentuan yang berlaku, jalan yang terbentuk itu secara normatif masih merupakan hak para pemilik tanah, dan pemerintah daerah tidak dapat mendaftarkan haknya karena legalitas perolehan tanahnya tidak dapat dibuktikan. Kondisi seperti itu hanya akan menimbulkan sengketa dikemudian hari. Awalnya kebijakan ini dibuat guna mengantisipasi permasalahan sengketa terkait akses jalan di antara masyarakat, namun setelah dilaksanakannya kebijakan hak servituut itu justru berpotensi menimbulkan sengketa antara masyarakat dengan Pemerintah.

Pelaksanaan penyerahan hak ini dapat dilakukan dengan dikoordinasi oleh Pemerintah Desa dan pemerintah daerah melalui surat penyerahan hak yang dibuat di depan dan disaksikan camat setempat atau Kepala Kantor Pertanahan. Terhadap bidang jalan yang telah terbentuk dapat dibuat sebagai suatu bidang tanah yang didaftarkan dalam kategori K3.3, sehingga ke depannya bidang tanah yang berupa jalan tersebut dapat dimohonkan sertipikat hak atas tanahnya oleh pemerintah daerah sebagai asetnya. Pelaksanaan penyerahan hak ini selain sebagai bentuk perlindungan hak masyarakat agar tidak tersandung kebijakan penyerahan hak atas tanahnya, juga upaya penertiban administrasi aset Pemerintah Daerah yang telah membangun jalan.

Urgensi penerbitan aturan terkait teknis pelaksanaan bagaimana asas fungsi sosial itu harus diterapkan, khususnya dalam jenis hak milik perlu segera dibuat. Hal tersebut guna menghindari perbedaan operasionalisasi yang dapat berbeda-beda di setiap Kantor Pertanahan. Selain dalam rangka melaksanakan tertib administrasi pertanahan, peraturan tersebut juga diharapkan dapat menjembatani pelaksanaan penertiban dan penataan ruang terkait fasilitas-fasilitas umum yang timbul dari asas fungsi sosial atas tanah yang dilakukan oleh pemerintah daerah.

\section{E. Kesimpulan}

Beberapa hal yang melatarbelakangi kebijakan hak servituut di Kabupaten Bekasi perlu diterapkan karena selain tidak adanya aturan yang mengatur perihal teknis pelaksanaan asas fungsi sosial atas tanah, juga terdapat beberapa hal yang riskan menimbulkan sengketa akses jalan. Halhal tersebut antara lain dualisme status jalan yang timbul dari hak servituut, perlindungan kepastian status jalan bagi masyarakat yang berada di sekitar kawasan pengembangan wilayah dan pembebasan tanah oleh perusahaan pengembang, serta nilai tanah yang relatif tinggi sehingga 
pemerintah tidak selalu dapat melaksanakan pengadaan tanah untuk pemenuhan seluruh kebutuhan jalan oleh masyarakat.

Implementasi hak servituut pada pelaksanaan PTSL di Kabupaten Bekasi telah mengalami pergeseran makna, dari pembebanan atau pembatasan penggunaan tanah menjadi kewajiban penyerahan sebagian hak atas tanah. Penyerahan hak oleh para pemilik tanah yang setuju untuk menyerahkan sebagian hak atas tanahnya menjadi jalan, pada pelaksanaan kegiatan PTSL hanya dibuat dalam dokumen administrasi yang berupa Surat Pernyataan Atas Batas Tanah dan Luas Tanah. Dalam hal peserta PTSL yang berkeberatan untuk menyerahkan sebagian hak atas tanahnya menjadi jalan, maka kategori bidang tanahnya dimasukkan dalam kategori K3 dan dibuatkan daftar tanahnya.

\section{Daftar Pustaka}

Agustina, R. (2003). Perbuatan melawan hukum. Jakarta: Program Pascasarjana Fakultas Hukum Universitas Indonesia.

Anggitiawan, R. (2016). Kesadaran Hukum Masyarakat Dalam Melaksanakan Pendaftaran Tanah Yang Masih Berupa Letter C Di Kabupaten Magetan. Jurnal Repertorium Edisi Khusus Program MKN FH Universitas Sebelas Maret Surakarta, 2(1), 106-124.

Dakhriawan, S. (2014). Tinjauan yuridis pengabdian pekarangan sebagai fungsi sosial dalam rangka pendaftaran tanah (studi di Kantor Pertanahan Kota Makassar) (Skripsi DIV). Sekolah Tinggi Pertanahan Nasional. Yogyakarta.

Fitra, E. (2014). Pelanggaran hak servituut (pengabdian pekarangan) warga Lengkong Gudang Serpong - Tangerang Selatan ditinjau dari Kitab Undang-undang Hukum Perdata (Skripsi S1). Universitas Trisakti. Jakarta.

Gueci, R. S. (2016). Penguatan Kedudukan Pranata Hak Servitut Dan Hukum Bertetangga Dalam Yurisprudensi, Jurnal Surya Kencana Dua: Dinamika Masalah Hukum dan Keadilan, 3(1), 154178.

Guntur, I. G. N., Suryanto, P. A. \& Sudirman, S. (2009). Makna pembatasan penggunaan tanah pada sertipikat hak atas tanah di Provinsi Bali, dalam Laporan Penelitian Strategis 2009 Buku II. Sekolah Tinggi Pertanahan Nasional. Yogyakarta.

Limbong, B. (2012). Hukum Agraria Nasional. Jakarta: Margatetha Pustaka.

Mujiburohman, D. A. (2016). Problematika Pengaturan Tanah Negara Bekas Hak Yang Telah Berakhir. BHUMI: Jurnal Agraria dan Pertanahan, 2(2), 151-164.

Parlindungan, A. P. (1999). Pendaftaran tanah di Indonesia (berdasarkan PP 24 tahun 1997). Bandung: Mandar Maju.

Sholihah, S. A. (2018). Penyelesaian sengketa akses jalan bidang tanah pekarangan (Studi di Kantor Pertanahan Kabupaten Sleman) (Skripsi DIV). Sekolah Tinggi Pertanahan Nasional. Yogyakarta. Soesangobeng, H. (2012). Filosofi, asas, ajaran, teori hukum pertanahan, dan agraria. Yogyakarta: STPN Press.

Wirandhana, E. (2017). Tinjauan Hukum Hak Servituut Jika Melintasi Tanah Milik Orang Lain. Jurnal Lex Administratum, $\mathrm{V}(6), 33-40$. 
Yusriadi (2010). Industrialisasi dan perubahan fungsi sosial hak milik atas tanah. Yogyakarta: Genta Publishing.

\section{Halaman Web}

Purnamasari, I.D. (2014, 3 Juni). Cara penyertifikatan tanah adat. Diakses tanggal 10 Juli 2021 dari https://www.hukumonline.com/klinik/detail/ulasan/lt537ac3b737835/cara-penyertifikatantanah-adat/

Sukoyo, Y. (2019, 27 Februari). Cegah konflik agraria, pemerintah percepat pendaftaran tanah. Diakses tanggal 13 Februari 2021, https://www.beritasatu.com/nasional/540338/ cegahkonflik-agraria-pemerintah-percepat-pendaftaran-tanah

Wahyono (2020, 8 Maret). Sejumlah kawasan industri besar di Indonesia. Diakses tanggal 13 Februari 2021, https://ekbis.sindonews. com/berita/1548361/34/sejumlah-kawasan-industri -besar-di-indonesia 